\title{
GENETIC BASIS OF COPPER RESISTANCE IN NEW ZEALAND STRAINS OF PSEUDOMONAS SYRINGAE
}

\author{
J.L. VANNESTE and M.D. VOYLE \\ HortResearch, Ruakura Research Centre, Private Bag 3123, Hamilton \\ Corresponding author: jvanneste@hortresearch.co.nz
}

\begin{abstract}
Strains of Pseudomonas syringae able to grow on minimal medium containing $500 \mathrm{mg} /$ litre of copper sulphate were selected from a collection of streptomycin-resistant strains isolated in New Zealand. From one of these copper-resistant strains a $1.3 \mathrm{~kb}$ fragment of DNA was isolated by PCR using primers designed on genes reported to be associated with copper resistance. Sequencing of this fragment revealed that a $572 \mathrm{bp}$ and a 275 bp portion had $98 \%$ and $95 \%$ similarity with ORFA of $P$. syringae pv. actinidiae, a gene that codes for copper resistance. Smaller portions of this $1.3 \mathrm{~kb}$ fragment were highly similar (89\% to $100 \%$ ) to portions of another gene involved in copper resistance (copA) from Pseudomonas syringae pv. tomato. Using this $1.3 \mathrm{~kb}$ fragment as a probe, homologous DNA was detected in eight other strains of $P$. syringae, which were all subsequently found to be resistant to copper.
\end{abstract}

Keywords: Pseudomonas syringae pv. actinidiae, Pseudomonas syringae pv. tomato.

\section{INTRODUCTION}

Control of plant pathogenic bacteria in New Zealand is mostly reliant on use of streptomycin and copper compounds. Copper compounds are particularly important as they are used by conventional and organic growers. Resistance to copper has been found overseas in plant pathogenic bacteria such as $P$. syringae pv. tomato (Bender \& Cooksey 1986), P. syringae pv. syringae (Sundin \& Bender 1993), as well as in non plant pathogenic bacteria such as Escherichia coli (Tetaz \& Luke 1983). Several genes have been associated with resistance to copper including the copA gene from strain PT23 of $P$. syringae pv. tomato (Bender \& Cooksey 1986) and pcoA gene carried in Escherichia coli by the plasmid pRJ1004 (Brown et al. 1995).

Although in New Zealand there is no report of disease control failure due to bacterial resistance to copper, the aim of this study was to evaluate the potential for the future development of such a resistance by screening a number of strains collected in New Zealand. The screening technique was based on the growth of strains on selective media and the subsequent genetic analysis was based on the detection of genes reported to be associated with copper resistance in strains isolated overseas.

\section{Strains and media}

\section{MATERIALS AND METHODS}

A total of 65 strains were evaluated for resistance to copper by their ability to grow on media supplemented with copper. The strains of $P$. syringae used in this study were streptomycin-resistant strains isolated between 1991 and 1994 in the Hawke's Bay area from pipfruit orchards where strains of Erwinia amylovora, the fire blight pathogen, resistant to streptomycin had been isolated (Thomson et al. 1993; Vanneste \& Voyle 2001). The strains $P$. syringae FF5 (Sundin \& Bender 1993) and P. syringae 7B40 (Sundin $\&$ Bender 1996) were used as a negative and a positive control, respectively. The complete medium used for growth of inoculum was Luria agar and the minimal medium was Ceria 132 (Vanneste et al. 1992). Minimal medium was supplemented with $500 \mathrm{mg} / \mathrm{litre}$ $\mathrm{CuSO}_{4} .5 \mathrm{H}_{2} \mathrm{O}$ for the screening of all strains for their resistance to copper. Bacterial colonies of the strain to be tested for copper resistance were transferred using a toothpick from Luria plates onto plates of minimal medium supplemented with copper. Up to 24 
colonies were transferred onto a single plate. A colony of 7B40 and one of FF5 were picked onto every plate. Plates were incubated at $28^{\circ} \mathrm{C}$ overnight before visual assessment for growth.

\section{DNA manipulation}

General DNA manipulations such as plasmid DNA preparation and DNA/DNA hybridisation were as described earlier (Vanneste et al. 1992). Total DNA was prepared according to Chen \& Kuo (1993). For hybridisation, DNA was blotted onto Hybond XL nylon membrane (Amersham Biosciences, Arlington Heights, IL, USA). The DNA probe containing the genes strA strB, which code for streptomycin resistance, was obtained by cutting plasmid RSF1010 with EcoR1 and PvuII. Probes were made using the Rediprime kit (Amersham Biosciences).

Polymerase chain reaction (PCR) was performed on a PTC 200 Peltier Thermal Cycler (M J Research Inc.) using $1 \mu \mathrm{l}$ of each overnight culture at ca $1 \times 10^{9} \mathrm{cfu} / \mathrm{ml}$. The following programme was used: $94^{\circ} \mathrm{C}$ for $3 \mathrm{~min}$, followed by 25 cycles of: $94^{\circ} \mathrm{C}$ for $45 \mathrm{~s}, 35^{\circ} \mathrm{C}$ for $45 \mathrm{~s}, 72^{\circ} \mathrm{C}$ for $10 \mathrm{~min}$, followed by a final extension period of $4 \mathrm{~min}$ at $72^{\circ} \mathrm{C}$. The two primers (copR and copF) were designed on the DNA sequence of two genes involved in resistance to copper, the copA gene isolated from strain PT23 of $P$. syringae pv. tomato (Bender \& Cooksey 1986) and the pcoA gene carried in Escherichia coli by the plasmid pRJ1004 (Brown et al. 1995). PCR products were purified using the Concert Rapid PCR Purification System (Gibco BRL Life Technologies, Inc. Rockville, MD, USA). PCR products were sequenced at Waikato Sequencing Facility by the Amersham Biosciences MegaBACE DNA Analysis system, which used dye terminator chemistry (Amersham Pharmacia Biotech UK Ltd., Buckinghamshire, England). DNA sequences were identified by comparing them with sequences in GenBank, EMBL, DDBJ and PDB databases using BLAST 2.2.1 (Altschul et al. 1997).

\section{RESULTS}

Eight of the 21 strains of $P$. syringae initially tested were able to grow on minimal medium supplemented with copper sulphate. Using the primers copR and copF, only the strain Saps1 of the eight strains identified as being copper resistant, yielded a DNA fragment by PCR. This fragment was about $1.3 \mathrm{~kb}$ long which was the expected size. It was sequenced from both ends using the primers designed for the PCR experiment. Analysis of the DNA sequences revealed that a 572 bp fragment was $98 \%$ similar to a portion of ORF A of $\mathrm{pPaCu} 1$, a plasmid identified as coding for copper resistance in a strain of $P$. syringae pv. actinidiae isolated in Japan (Nakajima et al. 2002). A 275 bp fragment was $95 \%$ similar to another portion of ORF A of $\mathrm{pPaCu} 1$. Smaller fragments ranging in size from 86 to $20 \mathrm{bp}$ were highly similar ( 89 to 100\%) to portions of copA from $P$. syringae pv. tomato.

When the $1.3 \mathrm{~kb}$ DNA fragment from Saps1 was used as a probe against total DNA extracted from a further 44 strains of streptomycin-resistant $P$. syringae strains isolated in New Zealand between 1992 and 1994, eight strains were found to carry DNA homologous to this fragment. They were 92Ps2, 92Ps5, 92Ps7, 92Ps8, 93Ps11, 93Ps20, 93Ps 21 and 93Ps28. These eight strains were able to grow on minimal medium supplemented with copper sulphate.

Of the eight strains of $P$. syringae above, seven yielded a fragment of DNA of ca $1.3 \mathrm{~kb}$, after conducting a PCR using the primers copR and copF. The DNA fragment obtained by the PCR from two of these strains, 92Ps8 and 93Ps11, was sequenced. Analysis of these DNA sequences revealed that fragments of a total length of $1.1 \mathrm{~kb}$ were $98 \%$ similar to DNA sequence of ORF A of $\mathrm{pPaCu} 1$ from $P$. syringae pv. actinidiae.

\section{DISCUSSION}

This is the first report of copper resistance in $P$. syringae strains isolated from New Zealand. In addition, several strains of P. fluorescens and Pantoea agglomerans (previously known as Erwinia herbicola) have also been found to be resistant to copper (J. Vanneste, unpubl. data). However, the genetic basis of resistance in these strains has 
yet to be studied. Genes that were found in some of the copper-resistant strains of $P$. syringae isolated in New Zealand are similar to genes that code for copper resistance in plant pathogenic strains isolated overseas. A similar situation has previously been found for streptomycin resistance; genes conferring streptomycin resistance in strains isolated in New Zealand were similar to $s t r \mathrm{~A} s t r \mathrm{~B}$, two genes found in strains isolated overseas (Vanneste \& Voyle 2001). The genes strA strB have often been found to be carried by plasmids. Similarly, genes that confer copper resistance in strains isolated overseas have been found to be carried by plasmids (Bender \& Cooksey 1986; Sundin \& Bender 1993; Brown et al.1995; Nakajima et al. 2002). In several instances plasmids which carried genes for copper resistance were also carrying streptomycin resistance (Sundin \& Bender 1993; Nakajima et al. 2002). All strains found resistant to copper in this study are also streptomycin resistant. The genetic basis of streptomycin resistance has been determined for some of these strains; they harbour plasmids that carry the genes strA strB (Vanneste \& Voyle 2001). All but two of the eight strains that carry genes similar to ORF A of pPaCul also carry strA strB on a plasmid (J. Vanneste, unpubl. data). Whether copper resistance in strains isolated from New Zealand is carried by plasmids and whether these plasmids also confer resistance to streptomycin will be determined in future work.

Although strains of pathogenic bacteria resistant to both copper and streptomycin have been isolated in New Zealand, no loss of control of bacterial diseases using copper or streptomycin has been reported in this country. However, it would be ecologically significant if plasmids that confer resistance to copper and streptomycin resistance were found in strains isolated from New Zealand. Some plasmids have the ability to transfer from one bacterium to another, even if these bacteria are from different species or even different genera (Sundin et al. 1994). This raises the possibility of selecting strains resistant to one of these compounds while using the other one. For example, the use of copper could help the spread of streptomycin-resistant plasmids, and vice versa. Since copper is used for control of bacterial and fungal diseases, this could result in streptomycin resistance in plant pathogenic bacteria. The spread of copper and streptomycin resistance in plant pathogenic bacteria would leave very few options for the control of bacterial diseases.

\section{ACKNOWLEDGEMENTS}

This project was funded by the Foundation for Research, Science and Technology.

\section{REFERENCES}

Altschul, S.F.; Madden, T.L.; Schaffer, A.A.; Zhang, J.; Zhang, Z.; Miller, W.; Lipman, D.J. 1997: Gapped BLAST and PSI-BLAST: a new generation of protein database search programs. Nucleic Acid Res. 25:3389-3402.

Bender, C.L.; Cooksey, D.A. 1986: Indigenous plasmids in Pseudomonas syringae pv. tomato: Conjugative transfer and role in copper-resistance. J. Bacteriol. 165: 534541.

Brown, N.L.; Barrett, S.R.; Camakaris, J.; Lee, B.T.O.; Rouch, D.A. 1995: Molecular genetics and transport analysis of the copper-resistance determinant ( $p c o$ ) from Escherichia coli plasmid pRJ1004. Mol. Microbiol. 17: 1153-1166.

Chen, W.; Kuo, T. 1993: A simple and rapid method for the preparation of gram-negative bacterial genomic DNA. Nucleic Acid Res. 21: 2260.

Nakajima, M.; Goto, M.; Hibi, T. 2002: Similarity between copper resistance genes from Pseudomonas syringae pv. actinidiae and $P$. syringae pv. tomato. J. Gen. Plant Pathol. 68: 68-74.

Sundin,G.W.; Bender, C.L. 1993: Ecological and genetic analysis of copper and streptomycin resistance in Pseudomonas syringae pv. syringae. Appl. Environ. Microbiol. 59: 1018-1024. 
Sundin,G.W.; Bender, C.L. 1996: Molecular analysis of closely related copper- and streptomycin- resistance plasmids in Pseudomonas syringae pv. syringae. Plasmid 35: 98-107.

Sundin,G.W.; Demezas, D.H.; Bender, C.L. 1994: Genetic and plasmid diversity within natural populations of Pseudomonas syringae with various exposures to copper and streptomycin bactericides. Appl. Environ. Microbiol. 60: 4421-4431.

Tetaz, T.J.; Luke, R.K. 1983: Plasmid-controlled resistance to copper in Escherichia coli. J. Bacteriol. 154: 1263-1268.

Thomson, S.V.; Gouk, S.C.; Vanneste, J.L.; Hale, C.N.; Clark, R.G. 1993: The presence of streptomycin resistance in pathogenic and epiphytic bacteria isolated in apple orchards in New Zealand. Acta Hort. 489: 671-672.

Vanneste, J.L.; Voyle, M.D. 2001: Characterisation of transposon, genes, and mutations which confer streptomycin resistance in bacterial strains isolated from New Zealand orchards. Acta Hort. 590: 493-495.

Vanneste, J.L.; Yu, J.; Beer, S.V. 1992: Role of antibiotic production by Erwinia herbicola Eh252 in biological control of Erwinia amylovora. J. Bacteriol. 174: 2785-2796. 